Review

\title{
Slag Behavior in Gasifiers. Part I: Influence of Coal Properties and Gasification Conditions
}

\section{Ping Wang * and Mehrdad Massoudi}

U.S. Department of Energy (DOE), National Energy Technology Laboratory (NETL), 626 Cochrans Mill Road, P.O. Box 10940, Pittsburgh, PA 15236-0940, USA; E-Mail: massoudi@netl.doe.gov

* Author to whom correspondence should be addressed, E-Mail: ping.wang@netl.doe.gov; Tel.: +1-412-386-7539; Fax: +1-412-386-5870.

Received: 30 October 2012; in revised form: 15 January 2013 / Accepted: 17 January 2013 / Published: 7 February 2013

\begin{abstract}
In the entrained-flow gasifiers used in integrated gasification combined cycle (IGCC) plants, the majority of mineral matter transforms to liquid slag on the wall of the gasifier and flows out the bottom. However, a small fraction of the mineral matter is entrained (as fly ash) with the raw syngas out of the gasifier to downstream processing. This molten/sticky fly ash could cause fouling of the syngas cooler. To improve gasification availability through better design and operation of the gasification process, a better understanding of slag behavior and the characteristics of the slagging process is needed. Char/ash properties, gas compositions in the gasifier, the gasifier wall structure, fluid dynamics, and plant operating conditions (mainly temperature and oxygen/carbon ratio) all affect slagging behavior. Because coal has varying ash content and composition, different operating conditions are required to maintain the slag flow and limit problems downstream. In Part I, we review the main types and the operating conditions of entrained-flow gasifiers and coal properties used in IGCC plants; we identify and discuss the key coal ash properties and the operating conditions impacting slag behavior; finally, we summarize the coal quality criteria and the operating conditions in entrained-flow gasifiers. In Part II, we discuss the constitutive modeling related to the rheological studies of slag flow.
\end{abstract}

Keywords: slag; viscosity; gasifier; integrated gasification combined cycle (IGCC); coal; operating conditions 


\section{Introduction}

Integrated gasification combined cycle (IGCC) is a promising clean coal technology with an inherent advantage of low emissions, and it has potential for cost-effective carbon dioxide $\left(\mathrm{CO}_{2}\right)$ capture to generate energy and chemicals [1]. IGCC without $\mathrm{CO}_{2}$ capture and sequestration (CCS) was demonstrated in four coal-based plants of Tampa Electric's Polk Power Station (United States), Wabash River (United States), NUON (The Netherlands), and ELCOGAS (Spain) [2-5]. IGCC with CCS and enhanced oil recovery (EOR) is included in federal supported demonstration projects and is currently under development [6]. For IGCC technology to become more competitive and fully commercial, low availability (defined as plant operation time during a certain period of time, usually 1 year) and high capital costs are the main challenges [7,8]. The gasification system caused approximately $6 \%$ unplanned outages after combined cycle power units (CCU), 17\% based on the demonstrated IGCC plants between 2001 and 2003 [4]. Low availability in the gasification system is largely due to slag buildup in the gasifier, fouling in the syngas cooler downstream of the gasification system and significantly, in the slurry feed of IGCC plants $[4,9,10]$. In addition, large amounts of unconverted carbon from the gasifier and failure of the refractory lining in the entrained-flow gasifiers are other major concerns [10]. These issues are related to slag behavior and influenced by fuel properties and operating conditions.

Entrained flow gasifiers are mostly used in IGCC applications to produce power and chemicals (e.g., ammonia, methanol, and acetic acid) [11]. In gasifiers, carbon in the coal particles is converted to syngas, and the mineral matters in the coal are transformed to ash/slag [12]. The majority of the ash is melted and deposited on the walls (i.e., refractory or membrane) of the gasifier, forming a liquid slag, which flows out of the bottom of the gasifier and finally solidifies in a water bath. However, a small fraction of the ash is entrained as fly ash with the raw syngas out of the gasifier to downstream processing [7]. Molten/sticky ash in the fly ash could cause fouling of the syngas cooler [7,13-15]. One method to reduce syngas cooler fouling is to maximize slag and minimize fly ash. For ash/intermediate char-slag particles to be trapped in the slag layer and not rebound (elastic reflection), particle surface stickiness and slag surface stickiness are critical [16,17] among many factors, such as particle velocity, surface tension, temperature, size, and impact angle [18,19]. Particles with certain carbon conversion at temperature above the ash fusion temperature are sticky [17]. Carbon conversion is affected by operating conditions (such as temperature, oxygen/carbon ratio, steam/oxygen ratio, pressure, and residence time) [16]. The stickiness of the slag layer is determined by its viscosity, which is the dominant factor determining the probability that ash particles will stick. Low temperature and high slag viscosity may solidify the slag and cause blockage of gasifier. To ensure continuous slag flow, temperature exceeding the ash flow temperature and temperature of critical viscosity, as well as a slag viscosity of less than $25 \mathrm{~Pa} \cdot \mathrm{s}$ (250 poise), are necessary [20]. In addition, at high temperature the molten slag layer can corrode/penetrate deeply into a gasifier's wall (i.e., refractory lining) even though the same layer can act as a thermal barrier to protect the wall at lower temperature [11,21]. This corrosion/penetration results in rapid refractory wearing/changing in the microstructure and properties of refractory that could cause possible cracking. Such problems will ultimately increase the maintenance time or reduce availability [21]. Therefore, understanding the key coal ash properties (i.e., ash fusion temperature, critical viscosity temperature, viscosity) and optimal operation conditions (i.e., 
temperature), as well as the characteristics of slag flow, are important to improving gasifier availability by improving the design and operation of the gasification process.

Slag behavior is affected by the properties of both gaseous and solid phases, gasifier wall structure, fluid dynamics, and operating conditions [22,23]. Under reducing environments (gasification), the viscosity at a given temperature is generally lower than under oxidizing atmospheres (conventional combustion). At elevated temperature, slag acts as a Newtonian fluid, and its viscosity usually decreases logarithmically as temperature increases. At lower temperature, crystallization or the separation of immiscible liquids may cause a dramatic increase in viscosity, and, as a result, the slag behaves as a non-liner viscoplastic fluid. Slag viscosity, along with temperature of critical viscosity $\left(\mathrm{T}_{\mathrm{cv}}\right)$, is used to characterize slag flow behaviors and is the most important parameter in selecting the operating temperature of the gasifier [24,25]. Because slag viscosity strongly depends on temperature and chemical composition, it could be optimized by raising/reducing the gasifier operating temperature or adding a flux or blend coals with low fusibility [22,26]. The viscosity model can be used as a guide for designing the gasifier, as well as determining the operation temperature, the amount of flux, and suitable coals for the gasifier [27,28]. Changes in coal result in changes in the composition of ash, which causes changes in the flow of slag within an existing gasifier and affects downstream processing. This study briefly introduces coal properties and operating conditions used in major commercial entrained-flow gasifiers in IGCC plants; identifies and discusses the key coal quality and operating conditions impacting slag flow behavior; summarizes the coal quality criteria and operating conditions for use in entrained-flow gasifiers. Part II will discuss the constitutive modeling related to rheological studies of slag flow.

\section{Major Commercial Entrained Flow Gasifiers and Operation Conditions in IGCC}

\subsection{Major Commercial Entrained Flow Gasifiers in IGCC}

The IGCC process typically comprises a gasification system and a power system (Figure 1) [9,16,20,29]. The gasification system includes coal preparation, a gasification reactor (gasifier), an air separation unit (ASU), gas cooling, and gas clean up. The majority of IGCC project applications use an entrained flow-type gasifier. A water-gas-shift reactor and $\mathrm{CO}_{2}$ separation unit may be added to obtain hydrogen-rich syngas and $\mathrm{CO}_{2}$ for sequestration. The power system is similar to those used in commercial modern natural gas (methane) fired power plants.

GE Energy (originally developed by Texaco), Shell, ConocoPhillips E-gas (originally developed by Destec) and Siemens (former GSP) gasifiers are the major commercial entrained-flow technologies used to generate raw syngas (Table 1 and Figure 2) [7,30]. The raw syngas generation process consists of hot raw syngas generation, quenching, and syngas cooling. In the hot raw syngas generation process, coal is fed to a gasifier by dry feed (Shell at the bottom of the gasifier, and Siemens at the top of the gasifer) or slurry feed (GE at the top of the gasifier, and E-gas at the bottom of the gasifier) in either a single stage (Shell, GE, and Siemens) or two stages (E-gas) [31,32]. Gasifying agents of steam and a limited amount of oxygen (from the ASU) are supplied via the top of the gasifier (Shell and Siemens, oxygen and steam; E-gas, oxygen) or the bottom of the gasifier (GE, oxygen). Under reducing conditions, the hot raw syngas is generated at high temperature (around $1500{ }^{\circ} \mathrm{C}$ ) and 
pressure in the gasifiers that have a refractory wall (GE and E-gas) or a membrane wall (Shell)/cooling screen (Siemens). Fluxing agents or additives, such as lime, may be added to optimize the ash melting point and adjust flow characteristics. Ash is formed and melted, the majority of which deposits on the walls of the gasifier and leaves the gasifier in a liquid flow as slag. The remaining ash/fly ash is entrained as a liquid in the syngas and may create a potential fouling problem for downstream process equipment, such as the syngas cooler. Therefore, prior to the hot syngas leaving the gasifier, it is quenched to solidify the melting fly ash and avoid fly ash with sticky surfaces. The quenched syngas leaves the gasifier at its top (Shell and E-gas) or its bottom (GE and Siemens). The sensible heat of the quenched syngas with a temperature around $900^{\circ} \mathrm{C}$ (GE Radiant cooling, Shell and E-gas in Figure 2) is recovered in a syngas cooler to produce steam for the steam turbine, except in cases where syngas is quenched using water at around $300{ }^{\circ} \mathrm{C}$ (GE Water quench and Siemens in Figure 2).

Figure 1. Function of oxygen and impact of process temperature on gasification in IGCC [9, 16,20,29].

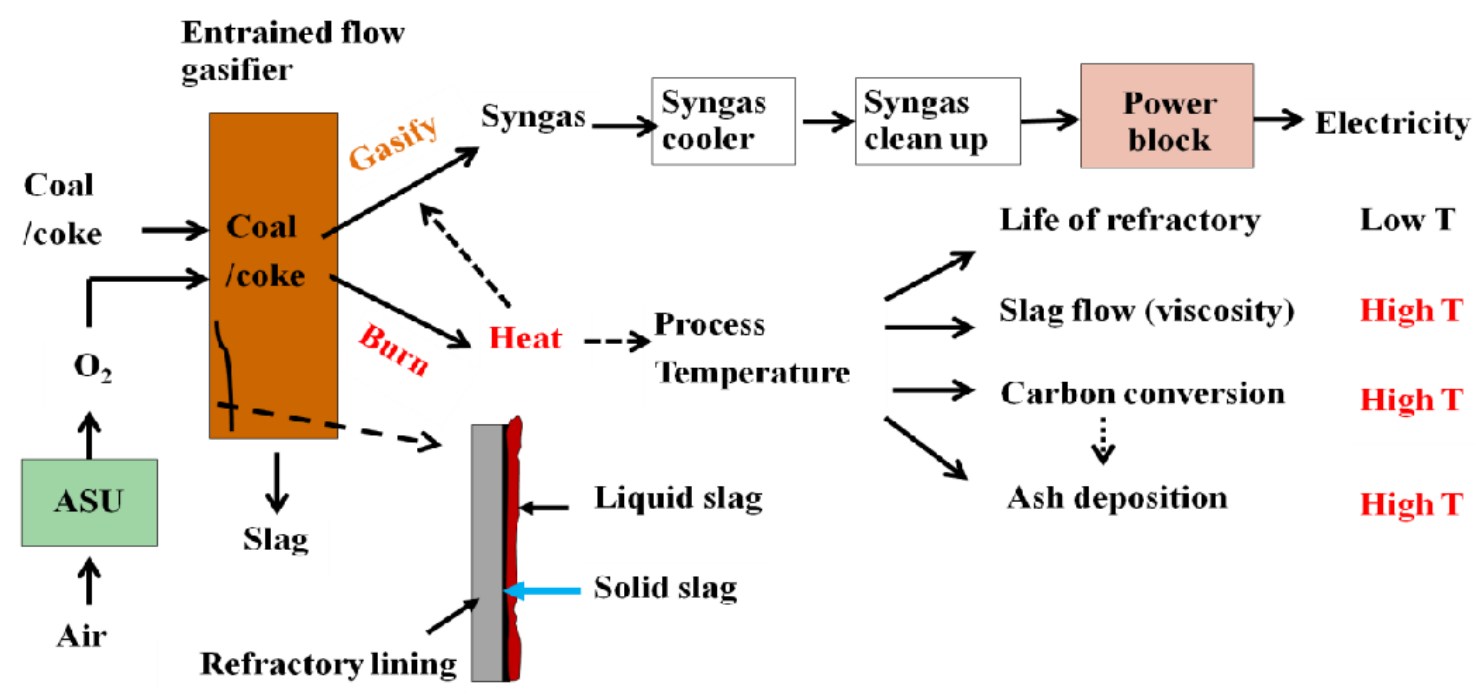

Table 1. Characteristics of major commercial entrained-flow technologies [3,7,30].

\begin{tabular}{|c|c|c|c|c|c|}
\hline $\begin{array}{l}\text { Gasification } \\
\text { Technology/ } \\
\text { Design feature }\end{array}$ & $\begin{array}{l}\text { Ge energy with } \\
\text { Radiant } \\
\text { Cooling }\end{array}$ & $\begin{array}{l}\text { Ge energy with } \\
\text { Water Quench }\end{array}$ & $\begin{array}{l}\text { Shell } \\
\text { Scgf }\end{array}$ & $\begin{array}{l}\text { Conocophillips } \\
\text { E-gas }\end{array}$ & $\begin{array}{l}\text { Siemens } \\
\text { Sfg }\end{array}$ \\
\hline Feed system & $\begin{array}{l}60 \%-70 \% \\
\text { coal/water } \\
\text { slurry; top feed }\end{array}$ & $\begin{array}{l}60 \%-70 \% \\
\text { coal/water } \\
\text { slurry; top feed }\end{array}$ & $\begin{array}{l}\text { Dry coal }(\sim 2 \% \\
\text { moisture } \\
\text { content }) / \mathrm{N}_{2} ; \\
\text { bottom feed }\end{array}$ & $\begin{array}{l}60 \text { to } 70 \% \\
\text { coal/water slurry; } \\
\text { bottom feed: } 1 \text { st } \\
\text { stage } 80 \% \text { and } \\
\text { 2nd stage } 20 \%\end{array}$ & $\begin{array}{l}\text { Dry feed } / \mathrm{N}_{2} \text { or } \\
\mathrm{CO}_{2} ; \\
\text { top feed }\end{array}$ \\
\hline Stage and flow & $\begin{array}{l}\text { Single stage } \\
\text { downflow }\end{array}$ & $\begin{array}{l}\text { Single stage } \\
\text { downflow }\end{array}$ & $\begin{array}{l}\text { Single stage } \\
\text { upflow }\end{array}$ & $\begin{array}{l}\text { Two stage } \\
\text { upflow }\end{array}$ & $\begin{array}{l}\text { Single stage } \\
\text { downflow }\end{array}$ \\
\hline Wall & Refractory & Refractory & Membrane & Refractory & $\begin{array}{l}\text { Cooling screen } \\
\text { (ash content }> \\
1-2 \mathrm{wt} \%)\end{array}$ \\
\hline Pressure (bar) & $30-80$ & $30-80$ & $30-40$ & $\sim 27$ & $\geq 40$ \\
\hline
\end{tabular}


Table 1. Cont.

\begin{tabular}{llllll}
\hline $\begin{array}{l}\text { Gasification } \\
\text { Technology/ } \\
\text { Design feature }\end{array}$ & $\begin{array}{l}\text { Ge energy with } \\
\text { Radiant } \\
\text { Cooling }\end{array}$ & $\begin{array}{l}\text { Ge energy with } \\
\text { Water Quench }\end{array}$ & $\begin{array}{l}\text { Shell } \\
\text { Scgf }\end{array}$ & $\begin{array}{l}\text { Conocophillips } \\
\text { E-gas }\end{array}$ & $\begin{array}{l}\text { Siemens } \\
\text { Sfg }\end{array}$ \\
\hline $\begin{array}{l}\text { Hot syngas } \\
\text { temperature }\left({ }^{\circ} \mathrm{C}\right)\end{array}$ & $1260-1500$ & $1260-1500$ & $1360-1650$ & $\begin{array}{l}1 \text { st stage } \\
1340-1400 ; 2 \text { nd } \\
\text { stage 1038 }\end{array}$ & 1400-1600 \\
\hline $\begin{array}{l}\text { Syngas } \\
\text { quenching } \\
\text { method }\end{array}$ & $\begin{array}{l}\text { Radiant cooling } \\
\text { then fire tube }\end{array}$ & $\begin{array}{l}\text { Water quench } \\
\text { (no syngas } \\
\text { cooler) }\end{array}$ & $\begin{array}{l}\text { Recirculated cold } \\
\text { syngas quench } \\
\text { then water tube } \\
\text { syngas cooler }\end{array}$ & $\begin{array}{l}\text { Chemical quench } \\
\text { then fire tube } \\
\text { syngas cooler }\end{array}$ & $\begin{array}{l}\text { Water quench } \\
\text { (no syngas } \\
\text { cooler) }\end{array}$ \\
\hline $\begin{array}{l}\text { Quenched syngas } \\
\text { temperature }\left({ }^{\circ} \mathrm{C}\right)\end{array}$ & $\sim 800$ & $\sim 300$ & $\sim 900$ & $\sim 1038$ & $\sim 230$ \\
\hline
\end{tabular}

Figure 2. Characteristics of the major commercial entrained-flow gasifiers [32].

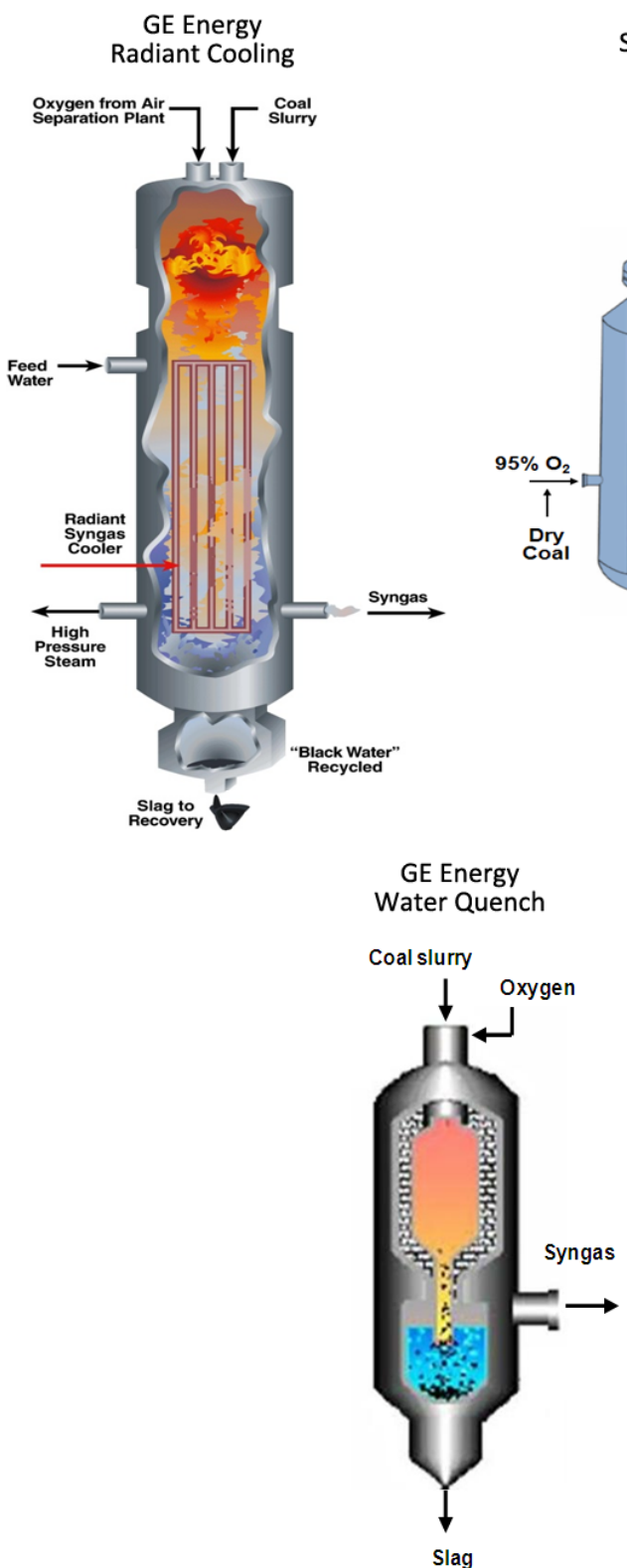

Shell SCGP

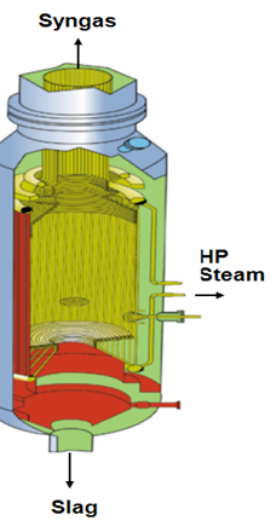

Siemens SFG

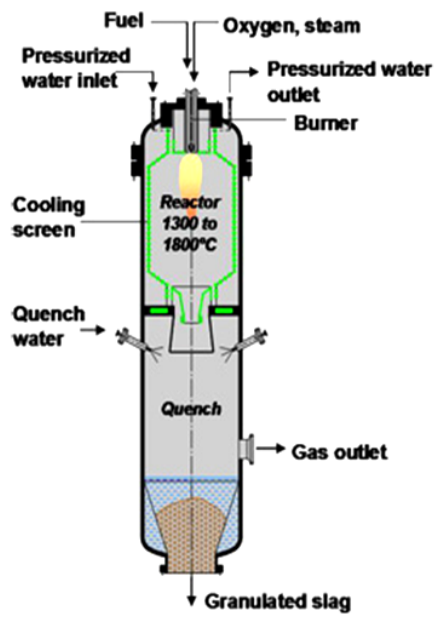


Two types of refractory linings and membrane walls are used in entrained-flow slagging gasifiers to protect the steel walls and reduce heat loss [33]. The E-gas and GE gasifiers use refractory linings, while membrane walls/cooling screens are used in the Shell gasifier and the Siemens, respectively. Refractory lining typically consists of three layers: an insulation layer of silica firebrick $\left(200-300{ }^{\circ} \mathrm{C}\right)$, a layer of castable bubble alumina, and a hotface refractory (Figure 1) [20,33]. The inner hotface refractory is usually a chromium oxide-based and/or zirconium oxide-based brick [20] and is worn by chemical corrosion (such as silica in the ash) and erosion (hot liquid slag). Although the refractory lining itself is inexpensive, repairs and/or replacements are frequent and costly. For example, Tampa Electric's Polk Power Station has a 20-30 day planned outage every two years [10].

The water-cooled membrane walls consist of high-pressure tubes, flat steel bridges that connect the tubes, and a thin layer of castable refractory (usually silicon carbide) [20,30]. Solid slag covers the wall surface, providing a protective layer. Membrane walls have a complex and expensive cooling and control system, but the walls have an estimated lifetime of about 20 years [20]. In addition, the heat loss with the membrane is $2 \%-4 \%$ of the heating value of the coal and is higher than heat loss with refractory linings, which is less than $1 \%$. The cooling screen used in the Siemens, which consists of spiral-wooded tubes filled with cooling water, also has the solid slag to cover the reactor wall [34].

\subsection{Fuels and Operating Conditions in Entrained Flow Gasifiers}

Coals, blends of coals, and petroleum coke blended with coals were tested in the IGCC plants to evaluate the fuel characteristics' impact on the IGCC process (i.e., carbon conversion and gasifier refractory) and demonstrate IGCC fuel flexibility [10]. As expected, preliminary tests showed low operating temperatures tend to result in low carbon conversion and long refractory life, but the low carbon conversion reduced efficiency and increased fly ash [10]. Table 2 lists coal properties used in demonstration IGCC plants and coal rank based on coal ASTM tests [10,29]. The tested coals were high-rank coals.

Table 2. Coal properties used in demonstration IGCC plants and coal rank $[5,10,29]$.

\begin{tabular}{|c|c|c|c|c|c|c|c|c|c|}
\hline \multicolumn{4}{|c|}{ Proximate analysis (\% wt) } & \multicolumn{2}{|c|}{ HHV (MJ/kg) (MF) } & \multicolumn{4}{|c|}{ Tested coal in ASTM coal rank } \\
\hline $\mathrm{MC}(\mathrm{AR})^{\mathrm{a}}$ & $\mathrm{VM}(\mathrm{MF})$ & $\mathrm{FC}(\mathrm{MF})$ & Ash (MF) & \multirow{2}{*}{\multicolumn{2}{|c|}{$23-33.2$}} & \multirow{2}{*}{\multicolumn{2}{|c|}{$\begin{array}{c}\text { Anthracitic } \\
\text { (Anth., semi-anth.) }\end{array}$}} & \multirow{2}{*}{ Bituminous } & \multirow{2}{*}{$\begin{array}{c}\text { subbituminous } \\
(\mathrm{A}, \mathrm{B})\end{array}$} \\
\hline $2.11-34$ & $10.6-46.6$ & $39.1-88.5$ & $0.5-35.0$ & & & & & & \\
\hline \multicolumn{10}{|c|}{ Ultimate analysis (\% MF) } \\
\hline $\mathrm{C}$ & $\mathrm{H}$ & $\mathrm{N}$ & $\mathrm{S}$ & $\mathrm{O}$ & $\mathrm{Cl}$ & \multicolumn{4}{|c|}{$\operatorname{Ash} \mathbf{T}_{25}\left({ }^{\circ} \mathrm{C}\right)$} \\
\hline $56.4-88.7$ & $3.27-5.2$ & $0.86-2.24$ & $0.13-4.61$ & $0.1-20.20$ & $0.01-0.41$ & \multicolumn{2}{|c|}{$1190->1500^{b}$} & \multicolumn{2}{|c|}{$1207-1549$} \\
\hline \multicolumn{10}{|c|}{ Ash mineral analysis (oxides \% wt. MF) } \\
\hline $\mathrm{SiO}_{2}$ & $\mathrm{Fe}_{2} \mathrm{O}_{3}$ & $\mathrm{Al}_{2} \mathrm{O}_{3}$ & $\mathrm{CaO}$ & $\mathrm{K}_{2} \mathrm{O}$ & $\mathrm{Na}_{2} \mathrm{O}$ & $\mathrm{P}_{2} \mathrm{O}_{5}$ & $\mathrm{TiO}_{2}$ & $\mathrm{MgO}$ & $\mathrm{SO}_{3}$ \\
\hline $24.2-59.8$ & $3.3-27.8$ & $9.5-33.3$ & $0.7-24.5$ & $0.1-3.9$ & $0.1-3.1$ & $0.1-1.5$ & $0.6-2.1$ & $0.3-3.7$ & $0.9-33.1$ \\
\hline
\end{tabular}

a. AR-as received; MF-moisture free; ${ }^{\text {b. }}$ Flux may be added to optimize the gasification temperature and oxygen consumption.

Entrained-flow gasifiers with high temperature and high pressure have been selected for the majority of IGCC projects (Table 1) [11]. The main advantage of using high-temperature entrained-flow gasifiers is to generate syngas that is free of oils and tars so that the related problems can be avoided [7]. 
The high reaction rate at the high temperature also allows single gasifiers to be built with large gas outputs sufficient to fuel large commercial gas turbines. High carbon conversion and low methane production are other benefits of high temperature. High-pressure syngas can be directly fed to a gas turbine to avoid large auxiliary power losses for syngas compression. It reduces the capital cost since it increases the capacity of the gasifier in volume. In addition, downstream syngas cleaning processes, such as $\mathrm{CO}_{2}$ capture, will be more efficient because of the increased partial pressure.

Gasifier operating conditions are determined by carbon conversion, ash slagging temperature or ash flow temperature of the coal, slag viscosity using $T_{25}$ temperature (the temperature at which the slag viscosity is $25 \mathrm{~Pa} \cdot \mathrm{s})$, and the temperature of critical viscosity $\left(\mathrm{T}_{\mathrm{cv}}\right)$. At same time, refractory life must be considered and balanced with coal conversion [35]. High amounts of unconverted carbon in the ash affect ash deposition on the gasifier walls [16], while fly ash with high unconverted carbon causes difficulties in downstream processing [9]. Low temperature and high slag viscosity may solidify the slag and cause slag blockage [9]. All these difficulties can be overcome by adding more oxygen to the gasifier in order to burn more coal and generate more heat. However, this reduces the overall efficiency of an IGCC system by increasing the parasitic power load of the air separation unit, reducing syngas yield, and, when a refractory-lined gasifier is used, shortening the life of the refractory [36,37]. For most coals, the ash melting point and the slag viscosity are more constraining than the carbon conversion considerations; therefore, the operating temperature of the gasifier is selected based on the ash slagging temperature or the ash flow temperature and the slag viscosity [9] — characteristics that are important for selecting the appropriate operating temperature of the gasifier to avoid either overfiring or solidifying the slag inside the gasifier.

Based on observations made at the Eastman Chemical Company, slag viscosity should be considered along with the ash melting temperature because coals with the same ash fusion temperature have different slag viscosities and, therefore, behave differently in the slag gasifier [8]. As shown in Figure 3, coal \#1 could run at a much lower temperature compared to coal \#2, according to Eastman Chemical Company data. The slag of coal \#2 would be very viscous even at $1399{ }^{\circ} \mathrm{C}(2550 \mathrm{~F})$. The high-temperature slag would wear the gasifier's refractory and reduce total gasification efficiency. Therefore, slag viscosity measurement is important in the gasifier along with ash slagging temperature.

Figure 3. Slag viscosity versus temperature for two different coals with the same ash fusion temperatures [8].

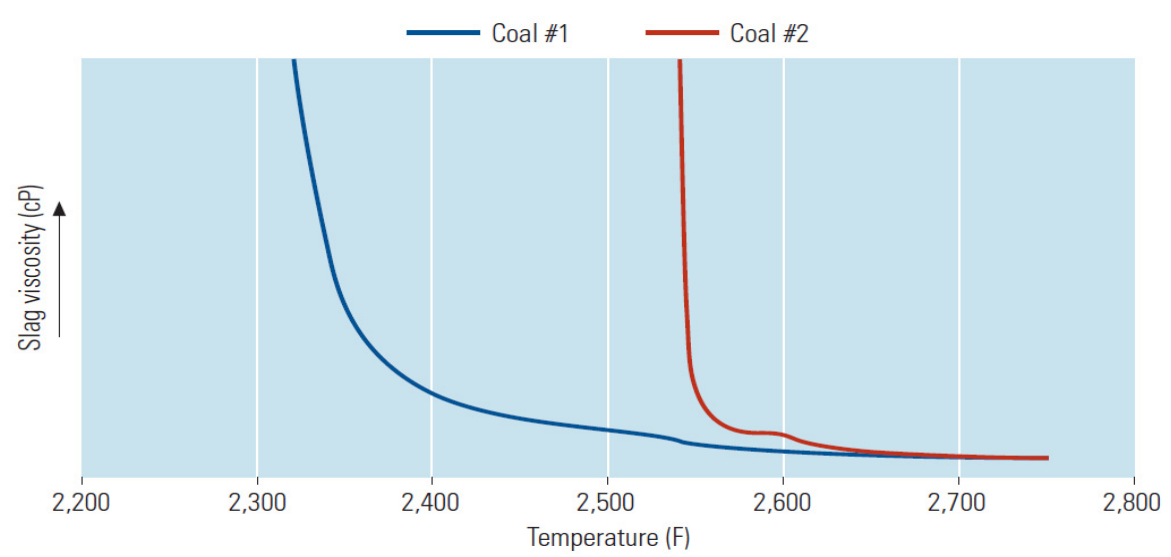


In the gasification process, oxygen is used to gasify solid carbon to syngas and generate heat to drive other gasification reactions along with the combustion of volatiles. In an ideal gasifier, a fixed amount of oxygen would be injected to react with carbon in the coal. However, in a real gasifier, additional oxygen is needed to increase the operating temperature in the entrained-flow gasifier above the slagging temperature or melting point, $\mathrm{T}_{25}$ and $\mathrm{T}_{\mathrm{cv}}$, of the ash by burning more carbon (i.e., carbon monoxide) to generate heat [9]. In addition, to ensure a near complete conversion to syngas, gasification processes typically operate above the stoichiometric oxygen/coal ratio. Compared to a typical combustion process, the amount of oxygen used in gasification is far less, typically less than half.

\section{Coal Properties and Qualities for Entrained Flow Slagging Gasifiers}

\subsection{Ash Content and Coal Composition}

Compared to other factors, such as price, heating value, sulfur content, and availability, coal ash content is the most important factor in selecting coal because coal ash content has the most impact on the performance of a slagging gasifier [8]. High-ash coals are not preferred because all the ash must be melted, which requires more heat and, therefore, more coal and carbon monoxide (CO) in syngas are burned. As a result, $\mathrm{CO}_{2}$ in syngas increases and cold gas efficiency reduces as ash content in the coal increases [20]. In addition, the high ash coals have an inherently high possibility of slag plugging in gasifier and fouling in syngas cooler [38]. Furthermore, if additional flux is required, the flux and its cost are proportional to the ash contents. Due to economic constraints, the ash content of coal (\% mass) for a slurry feeding gasifier is generally about $20 \%$ (considering the evaporation of water by heat) and about $40 \%$ for a dry feeding gasifier (Table 3) [20]. However, a reasonable amount of ash is required to coat the inner wall of a gasifier for insulating purposes and for protecting the membrane wall [38].

Table 3. Summary of criteria for coal ash properties for entrained-flow gasifiers [20,26,39].

\begin{tabular}{ccc}
\hline Coal ash properties & Criteria for entrained-flow gasifier & Reference \\
\hline Ash contents & $20 \%$ slurry feeding, $40 \%$ dry feeding & {$[20]$} \\
Ash Temperature (FT) & $<1400{ }^{\circ} \mathrm{C}$ is optimal, but $1500{ }^{\circ} \mathrm{C}$ is acceptable; $>1500{ }^{\circ} \mathrm{C}$ flux is needed & {$[26]$} \\
Ash composition & silica ratio $100 \mathrm{SiO}_{2} /\left(\mathrm{SiO}_{2}+\mathrm{Fe}_{2} \mathrm{O}_{3}+\mathrm{CaO}+\mathrm{MgO}\right)<80 ; \mathrm{SiO}_{2} / \mathrm{Al}_{2} \mathrm{O}_{3}$ & {$[26]$} \\
Temperature of critical & ratio of $1.6-2.0$ is optimal for minimum flux amount & {$[26]$} \\
viscosity $\left(\mathrm{T}_{\text {cv }}\right)$ & $<1400{ }^{\circ} \mathrm{C}$ is preferred & {$[26]$} \\
Viscosity & $5-25 \mathrm{~Pa} \cdot \mathrm{s}$ at 1400 to $1500{ }^{\circ} \mathrm{C}$; Optimum $15 \mathrm{~Pa} \cdot \mathrm{s}$ & \\
\hline
\end{tabular}

Coal is a heterogeneous material and consists of organic (macerals) and inorganic (mineral matter) components [40]. The organic matter is primarily composed of carbon, hydrogen, and oxygen, with lesser amounts of nitrogen and sulfur that are sources of environmental pollutants [41]. The inorganic fraction is commonly identified as ash, subsequent to combustion and gasification, and causes problems (such as fouling) during coal combustion and gasification. There are three forms of inorganic constituents distributed in coal: (1) organically associated elements (other inorganic constituents); (2) inherent minerals closely associated with coal; and (3) excluded mineral matter that readily 
separates from coal [42]. The main minerals in coal include kaolinite, quartz, aluminosilicates, pyrite, dolomite, and calcite, along with unknown phases [43].

During gasification, these minerals may form a new phase [44]. In the gasifier, mineral matter/inorganic components are transformed into vapors (such as vaporized inorganic components), liquids (melting ashes), and solids [42,43,45,46]. The intermediate ash species, produced during gasification, deposit and form slag or become entrained with the ash and flow out of the gasifier with flue gas as fly ash [42]; the slag and fly ash have different chemical compositions [47]. The fly ash and volatile compounds flow out of the gasifier. The vaporized inorganic components may condense, or the melting fly ash (not solidified by syngas quenching) may deposit in syngas coolers and cause different types of fouling [40]. In liquid-phase slag, the major bonding components are derived from the included (inherent) minerals, such as calcium, in carbon-rich particles [43]. The ash formed during gasification is a chemically reduced species, such as sulfides and metals, which have different properties from their oxidized counterparts in combustion $[42,48]$.

\subsection{Chemical Composition of Ash in Coal}

The chemical composition of coal ash is an important factor in slagging gasifiers because it affects ash fusibility, slag viscosity, and refractory life. Silicon dioxide $\left(\mathrm{SiO}_{2}\right)$, aluminum oxide $\left(\mathrm{Al}_{2} \mathrm{O}_{3}\right)$, ferric oxide $\left(\mathrm{Fe}_{2} \mathrm{O}_{3}\right)$, titanium oxide $\left(\mathrm{TiO}_{2}\right)$, phosphorus pentoxide $\left(\mathrm{P}_{2} \mathrm{O}_{5}\right)$, calcium oxide $(\mathrm{CaO})$, magnesium oxide $(\mathrm{MgO})$, sodium oxide $\left(\mathrm{Na}_{2} \mathrm{O}\right)$, potassium oxide $\left(\mathrm{K}_{2} \mathrm{O}\right)$, and sulfur trioxide $\left(\mathrm{SO}_{3}\right)$ are the major components of coal ash [15,20,43]. Ash compositions in mass percent are 50.1 $\mathrm{SiO}_{2}, 23.3 \mathrm{Al}_{2} \mathrm{O}_{3}$, 6.4 $\mathrm{Fe}_{2} \mathrm{O}_{3}, 1.0 \mathrm{TiO}_{2}, 0.7 \mathrm{P}_{2} \mathrm{O}_{5}, 8.1 \mathrm{CaO}, 2.7 \mathrm{MgO}, 0.4 \mathrm{Na}_{2} \mathrm{O}, 0.8 \mathrm{~K}_{2} \mathrm{O}$, and $6.1 \mathrm{SO}_{3}$ [43]. These components mainly contribute to the melting characteristics of the ash. All these components, specifically the calcium and iron contents are believed to be indicators for ash fusion properties. $\mathrm{CaO}$ in particular is an important factor in the viscous properties of slag $[43,49]$. As the $\mathrm{CaO}$ content increases, the viscosity of slag increases. Trace components, such as mercury, chlorine, fluorine, etc., contribute greatly to the environmental issues associated with coal usage. However, in comparing ash from a laboratory muffle furnace with slag from an industrial gasifier, it was found that the major oxide content $\left(\mathrm{Al}_{2} \mathrm{O}_{3}\right.$ and $\left.\mathrm{Fe}_{2} \mathrm{O}_{3}\right)$ and trace compositions in ash are higher than those in slag [50]. Certain chemical components of coal ash (i.e., $\mathrm{CaO}, \mathrm{SiO}_{2}, \mathrm{Fe}_{2} \mathrm{O}_{3}$ ) can attack the refractory and cause cracks [30]. In addition, residence time affects the amount and composition of ash formed in a high-temperature gasifier [51].

Ash composition could be used to assess slag viscosities, flow temperatures, and flux requirements [26]. In addition, indices (slagging and fouling) based on ash compositions could be used to guide operations and evaluate coal quality for gasification or to describe ash slagging or fouling behavior. There are many proposed indices, but most of them have limited application because they are not based on physical principles. The base-acid ratio $\mathrm{R}$ as $\left(\mathrm{CaO}+\mathrm{MgO}+\mathrm{Fe}_{2} \mathrm{O}_{3}+\mathrm{Na}_{2} \mathrm{O}+\mathrm{K}_{2} \mathrm{O}\right) /\left(\mathrm{SiO}_{2}+\right.$ $\mathrm{Al}_{2} \mathrm{O}_{3}+\mathrm{TiO}_{2}$ ) can be used for all ranks of coal [52]. Coal with $\mathrm{R}$ in the range of 0.4-0.7 has low fusibility temperature and higher slagging potential [41]. Another slagging index is Rs as RxS, where $\mathrm{S}$ is the wt \% sulfur in the dry coal. Some fouling indices are $\mathrm{R}_{\mathrm{F}}$ as $\mathrm{RxNa}_{2} \mathrm{O}$ and chlorine content of coal to predict fouling of convective heating surface. For blended coals, the fouling index $\mathrm{Na}_{2} \mathrm{O}(\mathrm{g} / \mathrm{GJ})$ is better than $\mathrm{R}_{\mathrm{F}}$ [52]. Other factors are silica/alumina ratio $\left(\mathrm{SiO}_{2} / \mathrm{Al}_{2} \mathrm{O}_{3}\right)$, iron/calcium ratio $\left(\mathrm{Fe}_{2} \mathrm{O}_{3} / \mathrm{CaO}\right)$, 
a dolomite percentage (DP) $100(\mathrm{CaO}+\mathrm{MgO}) /\left(\mathrm{Fe}_{2} \mathrm{O}_{3}+\mathrm{CaO}+\mathrm{SiO}_{2}+\mathrm{MgO}+\mathrm{Na}_{2} \mathrm{O}+\mathrm{K}_{2} \mathrm{O}\right)$, and a silica percentage (SP) $100 \mathrm{SiO}_{2} /\left(\mathrm{SiO}_{2}+\mathrm{Fe}_{2} \mathrm{O}_{3}+\mathrm{CaO}+\mathrm{MgO}\right)$. For blended coal, $\mathrm{Fe}_{2} \mathrm{O}_{3} / \mathrm{CaO}$ molar ratio correlates to slagging propensity [53]. All these indices and factors are derived from coal combustion and may be applied to coal gasification.

Patterson and Hurst [26] studied a range of Australian bituminous coals using laboratory tests for the entrained-flow slagging gasifier. They proposed that a silica ratio of $100 \mathrm{SiO}_{2} /\left(\mathrm{SiO}_{2}+\mathrm{Fe}_{2} \mathrm{O}_{3}+\mathrm{CaO}\right.$ $+\mathrm{MgO})<80$ is required for entrained-flow gasifiers. Flux (such as limestone) is required for coal with a higher silica ratio. To minimize the flux amount, a $\mathrm{SiO}_{2} / \mathrm{Al}_{2} \mathrm{O}_{3}$ ratio of $1.6-2.0$ is optimal. Low-temperature fouling of various coals under gasification conditions was studied using a drop tube furnace [54], with fouling related to $\mathrm{R}_{\mathrm{ba}}$ ratio of $\%\left(\mathrm{MgO}+\mathrm{CaO}+\mathrm{K}_{2} \mathrm{O}\right) / \%\left(\mathrm{SiO}_{2}+\mathrm{Al}_{2} \mathrm{O}_{3}\right) . \mathrm{R}_{\mathrm{ba}}$ in the bottom layer of fouling in the probe is higher in the top layer. Since $\%(\mathrm{MgO}+0.719 \mathrm{CaO})$ in coal is high, the coal demonstrates a propensity towards fouling.

\subsection{Ash Fusibility and Ash Flow Temperature}

Ash fusion temperature is an important index for all gasifiers. It can strongly influence the formation of slag [43]. The ASTM D-1857 ash fusibility test (AFT) is designed to simulate the behavior of coal ash when it is heated in either a reducing or an oxidizing atmosphere. The test is the most accepted method of assessing the propensity of coal ash to slag and gives an average flow property. It measures approximate temperatures at which the ash cone will sinter (i.e., the solid ash particles will weld together without melting), melt, and flow. Four temperatures are reported: the initial deformation temperature (IDT), the softening temperature (ST), the hemispherical temperature (HT), and the flow temperature (FT) [55]. For blended coal ash, thermo-mechanical analysis (TMA) was used to characterize ash fusibility because TMA temperatures changed with blended proportions of coals while AFT did not [56].

For gasification applications, the fusion characteristics of the ash should be determined under reducing conditions since these results are generally lower than those observed under oxidizing conditions (Figure 4) [52,57]. For entrained-flow slagging gasifiers, ash softening and ash-melting or fusion temperatures are important variables. ST is related to ash particle deposition. If the temperature of the ash particles is higher than the ST, the particles become sticky and tightly bond to surfaces [41]. An operating temperature exceeding FT is essential to ensure that the ash flows continuously [58]. It would be better for the operating temperature to be about $100^{\circ} \mathrm{C}$ above the FT because FT variation of a coal from the same mine could be as high as $70{ }^{\circ} \mathrm{C}$ since the ash content changes about $2 \%$ during a year [13]. A flow temperature under a reducing environment of $<1400{ }^{\circ} \mathrm{C}$ is optimal and up to $1500{ }^{\circ} \mathrm{C}$ is acceptable [26]. Under these conditions, little or no flux is required. Coals with the flow temperatures $>1500{ }^{\circ} \mathrm{C}$ require additional flux. However, if the FT is below $1260{ }^{\circ} \mathrm{C}$ with high ash content, the possibility of fouling a downstream heat exchanger, such as the syngas cooler, by fly ash increases and more precaution should be practiced to prevent the fouling [38]. 
Figure 4. Ash fusion temperature under reducing and oxidizing conditions of selected coals [57].

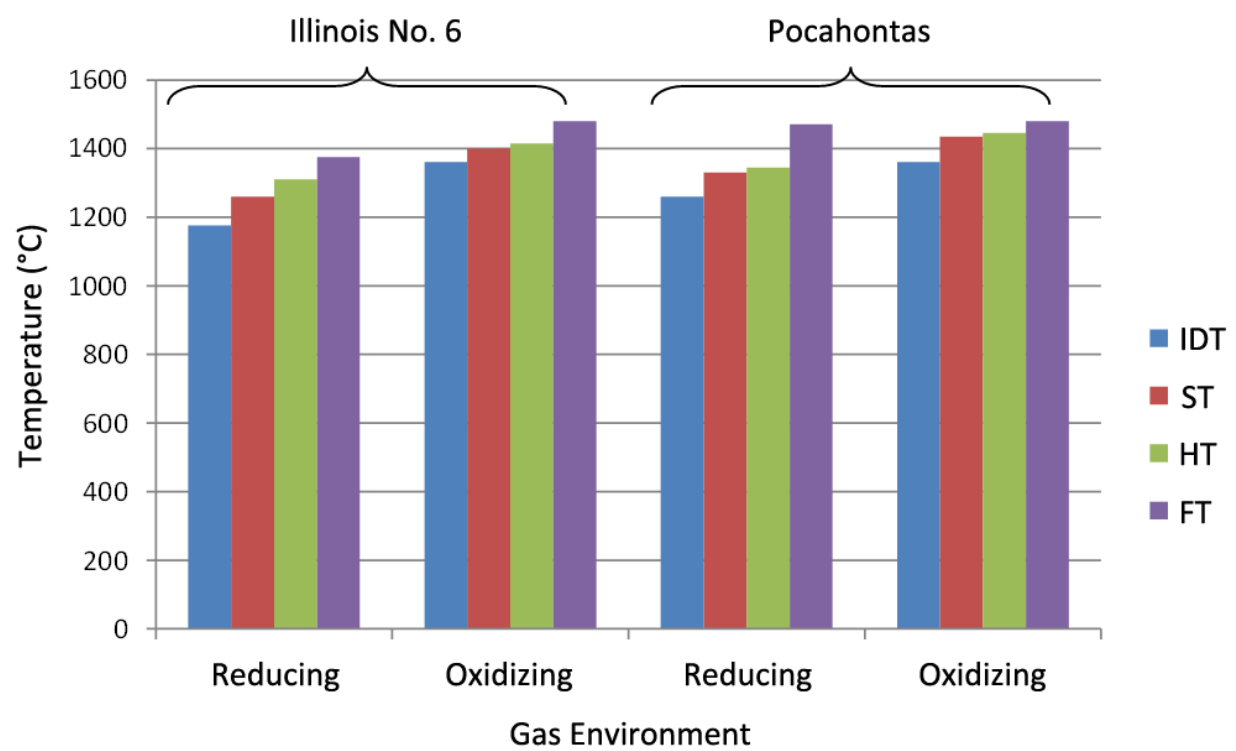

The effects of the chemical composition of ash on fusion temperatures were studied using regression analysis for 1250 ash samples of Eastern and Western coals [46,59]. For gasification under reducing conditions, the ratio of $\mathrm{SiO}_{2} / \mathrm{Fe}_{2} \mathrm{O}_{3}$ correlates most strongly with temperature then $\mathrm{Fe}_{2} \mathrm{O}_{3}$ content. Under oxidizing conditions, the ratio of $\mathrm{SiO}_{2}$ and $\mathrm{CaO}$ is most strongly correlated with temperature. Song et al. [60] investigated $\mathrm{CaO}, \mathrm{Fe}_{2} \mathrm{O}_{3}$, and $\mathrm{MgO}$ on fusion temperatures under argon using the thermodynamic computer package FactSage. The fusion temperatures of coal ash decrease with increasing $\mathrm{CaO}, \mathrm{Fe}_{2} \mathrm{O}_{3}$, and $\mathrm{MgO}$ contents then increase after reaching a minimum; for example, when $\mathrm{CaO}$ is higher than $35 \%$ the fusion temperature increases rapidly [50]. In general, if both iron and calcium are high in coal, the softening and melting temperatures will be reduced [20]. Conversely, fusion temperatures increase as $\mathrm{SiO}_{2} / \mathrm{Al}_{2} \mathrm{O}_{3}$ ratios increase. The acid components of $\mathrm{Al}_{2} \mathrm{O}_{3}, \mathrm{SiO}_{2}$, and $\mathrm{TiO}_{2}$ all increase the ash flow temperature, with aluminum having the strongest effect [61].

\subsection{Slag Viscosity}

In addition to ash softening and melting temperatures, slag viscosity is an important property of ash. For slagging gasifiers, the relationship between slag viscosity and temperature is critical since it determines the flow characteristics of the slag. Coals with the same ash fusion temperature may have different slag viscosities and, therefore, behave differently in the slag gasifier [8,20,38]. For entrained-flow gasifiers, viscosity up to $15 \mathrm{~Pa} \cdot \mathrm{s}$ is optimal, and $25 \mathrm{~Pa} \cdot \mathrm{s}$ is the maximum to keep reliable continuous slag tapping [26]. The temperature is represented as $T_{25}$ because the viscosity is $25 \mathrm{~Pa} \cdot \mathrm{s}$ [20]. Viscosity is strongly dependent on the temperature and chemical compositions of ash. For a more detailed discussion of the constitutive modeling related to the rheological studies of slag see Massoudi and Wang [62]. Figure 5 shows a simplified relationship between ash fluid properties and chemical composition [20]. The $\mathrm{T}_{25}$ temperature varies with the base-acid ratio $\mathrm{R}$ $\left(\mathrm{CaO}+\mathrm{MgO}+\mathrm{Fe}_{2} \mathrm{O}_{3}+\mathrm{Na}_{2} \mathrm{O}+\mathrm{K}_{2} \mathrm{O}\right) /\left(\mathrm{SiO}_{2}+\mathrm{Al}_{2} \mathrm{O}_{3}+\mathrm{TiO}_{2}\right)$. 
Slag viscosity could be measured using a high-temperature rotational viscometer/rheometer, or it could be estimated from the composition of the ash in the gasifier feed stream. The rheological behavior of the slag is affected by the shear rate and temperature [50]. The sensitivity of the slag viscosity to temperature decreased with increasing rotation speed. These laboratory tests are suitable for comparing coal ash slag, but it should be remembered that the measured viscosities can only be used as an indication of slag behavior in the gasifier. Other factors, such as particulate carbon content, extent of iron reduction, and operating parameters, may affect actual slag behavior [20]. The prediction method is limited because some partitioning of the ash species occurs within the gasifier, with more volatile species exiting with the gas phase [9]. In addition, slag viscosity may be changed as slag compositions change during the gasification process. The slag viscosity may increase due to formation of metallic iron from iron compounds in the ash, slag by the reducing atmosphere, or unconverted char during gasification [63].

Figure 5. Fluid point temperature of slag $\left(\mathrm{T}_{25}\right)$ versus base-acid ratio [20].

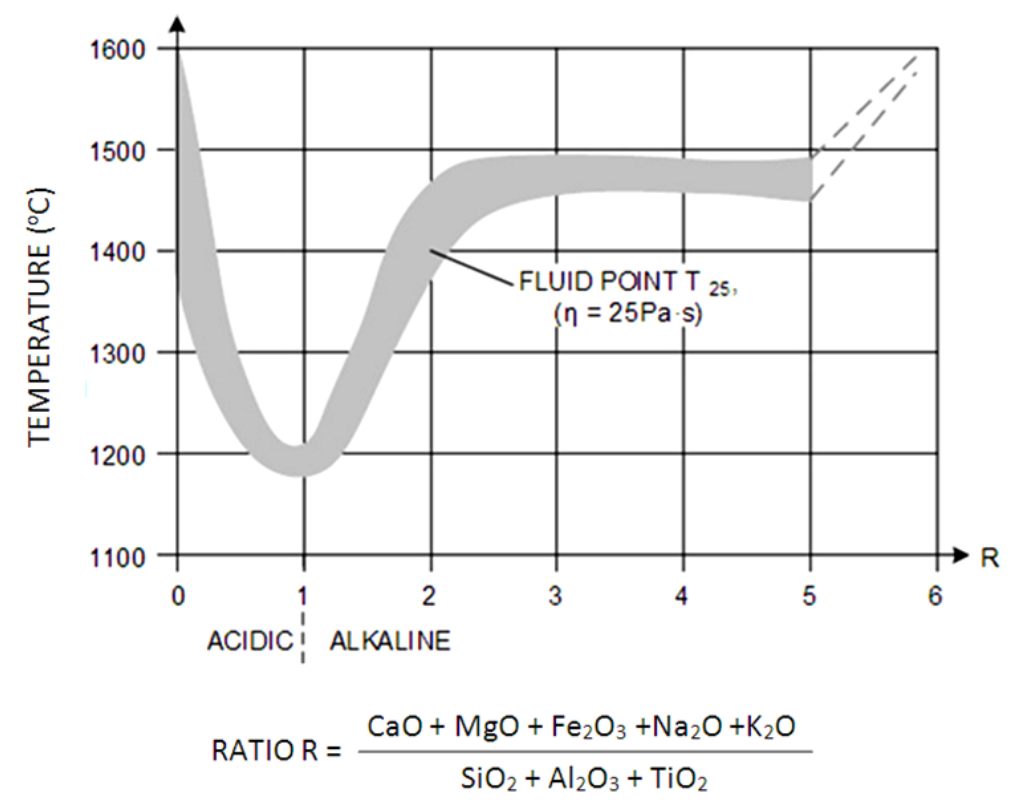

\subsection{Temperature of Critical Viscosity}

Viscosity is important in establishing the rate of slag flow, but the $\mathrm{T}_{\mathrm{cv}}$ is equally significant in determining whether the slag will continue to flow as it cools upon leaving the slagging gasifier. As the liquid slag cools, solids precipitate out. While the solids reach a certain value ( $15 \%-34 \%$ by mass), the viscosity increases drastically [64]. At the $\mathrm{T}_{\mathrm{cv}}$, the relationship of viscosity to temperature changes, and the viscosity rises more steeply (Figure 3, coal \#2). Some components begin to crystallize, and the slag enters the plastic intermediate zone between the liquid and solid phases [20]. Some (friendly) slags have a relatively gentle initial deviation from the linear relationship, but other (unfriendly) slags have a rapid rise in viscosity at temperatures below the $T_{c v}$. The $T_{c v}$ is used to set the minimum temperature for slag tapping to avoid slag tapping problems. For a slagging gasifier operating at a reasonable temperature, it is necessary that the $\mathrm{T}_{\mathrm{cv}}$ be less than $1400{ }^{\circ} \mathrm{C}$, which allows lower gasification temperature and, thus, higher cold gas efficiencies [20,26]. 
Predicting the $\mathrm{T}_{\mathrm{cv}}$ is difficult because $\mathrm{T}_{\mathrm{cv}}$ depends on the separation of the crystallization phase in the molten slag. The $T_{c v}$ may be undetected in a routine viscosity measurement until so much solid has accumulated that the slag freezes. Ilyushechkin and Kinaev [65] studied $\mathrm{T}_{\mathrm{cv}}$ with the amount of the precipitated solids using a synthetic slag $\mathrm{SiO}_{2}-\mathrm{Al}_{2} \mathrm{O}_{3}-\mathrm{CaO}-\mathrm{FeO}$ system and concluded that there were no direct relationships between phase compositions of melting and $\mathrm{T}_{\mathrm{cv}}$. Predicting $\mathrm{T}_{\mathrm{cv}}$ based on ash chemical composition was not reliable [46]. The correlation between $\mathrm{T}_{\mathrm{cv}}$ and the ash $\mathrm{ST}$ was also poor. It can be improved by adding $110{ }^{\circ} \mathrm{C}(200 \mathrm{~F})$ to the $\mathrm{ST}$ [46]. The $\mathrm{T}_{\mathrm{cv}}$ predicted in this method can only be used as reference. Song et al. [66] derived an empirical equation to correlate $\mathrm{T}_{\mathrm{cv}}$ of 40 synthetic ash samples with liquidus temperature (i.e., the temperature at which solids begin to precipitate as liquid slag is cooling) and accurately predicted $\mathrm{T}_{\mathrm{cv}}$ of eight Chinese coal ash samples. The liquidus temperature is calculated by FactSage using a synthetic slag $\mathrm{SiO}_{2}-\mathrm{Al}_{2} \mathrm{O}_{3}-\mathrm{CaO}-\mathrm{Fe}_{2} \mathrm{O}_{3}-\mathrm{MgO}$ system.

\section{Impact of Operating Conditions on Flow Behaviors of Coal Slag in Entrained Flow Gasifiers}

\subsection{Slag Viscosity with Temperature and Slag Compositions}

In the entrained-flow gasifier, the slag deposited on the walls is multi-layered and changes from fully liquid slag, or partly crystallized slag, into solid slag as temperatures decrease [67]. Oh et al. [68] investigated the effect of temperature and the formation of crystalline phases on slag viscosity under gasification conditions. Four coal samples were used: SUFCo (Hiawatha seam, high volatile C bituminous rand), Pittsburgh \#8 bituminous, and two Powell Mountain (PM) coals (unwashed PM coal-PMA and washed PM coal-PMB). SUFCo and PMA were gasification slag samples. Pittsburgh $\# 8$ and PMB were treated at $750{ }^{\circ} \mathrm{C}$ under air. Figure 6 shows how the viscosities of the four slags changed with temperature [68].

Figure 6. Slag viscosity changes with temperature [68].

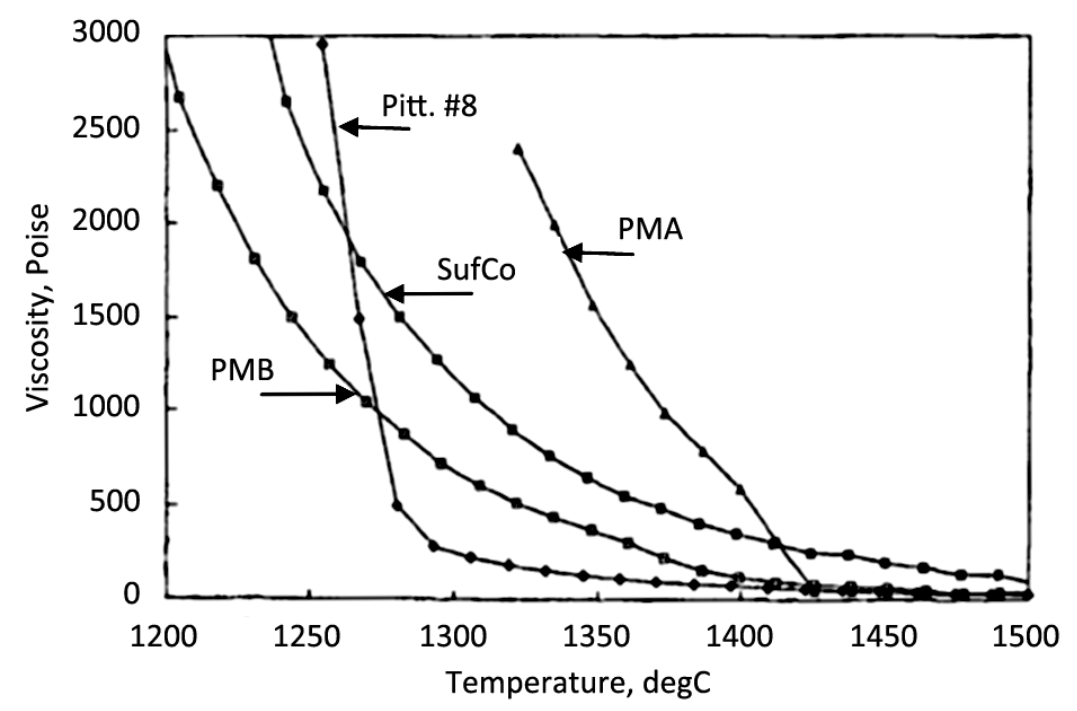

The viscosity of SUFCo and PMB slags gradually increased as temperature decreased, which indicates glassy slag phase. The viscosity of Pittsburgh \#8 and PMA, on the other hand, increased rapidly as the temperature decreased, which is typical of crystalline slags (non-Newtonian). The 
SUFCo slag had high concentrations of $\mathrm{SiO}_{2}$ and $\mathrm{CaO}$ and low concentrations of $\mathrm{Al}_{2} \mathrm{O}_{3}$ and $\mathrm{FeO}$ compared to the Pittsburgh \#8 slag. Both PMA and PMB slag compositions are close to the Pittsburgh \# 8 slag. In addition, Lin et al. [69] studied viscosities of three typical Asian coal ashes/slags and concluded that the slag flow properties are strongly related to microstructure of the slag along with its composition.

Slag composition strongly influences viscosity, but its mechanism is not well understood. Network theory divides individual element oxides of ash into three groups according to their effect on the silica network. The groups are network formers (increasing the slag viscosity), modifiers (decreasing the slag viscosity), and no defined roles [70]. $\mathrm{SiO}_{2}$ is the dominant network former. The alkali oxides (such as $\mathrm{Na}_{2} \mathrm{O}, \mathrm{K}_{2} \mathrm{O}$, and $\mathrm{Li}_{2} \mathrm{O}$ ) are network modifiers. The alkaline earth oxides (such as $\mathrm{MgO}$ and $\mathrm{CaO}$ ) are usually network modifiers, but their roles are also dependant on the overall composition of the slag. The viscosity of slag with high concentrations of $\mathrm{Ca}$ and $\mathrm{Mg}$ changes sharply with temperature and sometimes increases $\mathrm{T}_{\mathrm{cv}}$. Kato and Minowa [71] used synthesized slags of $\mathrm{CaO}-\mathrm{SiO}_{2}-\mathrm{Al}_{2} \mathrm{O}_{3}$ to study viscosities of the slag at elevated temperature and the effects of adding oxide, fluorides, and chlorides on the slag viscosities. The viscosity increased with increasing $\mathrm{Al}_{2} \mathrm{O}_{3}$ or $\mathrm{SiO}_{2}$ contents, while $\mathrm{CaO}$ lowered these values. The addition of $\mathrm{FeO}, \mathrm{TiO}_{2}, \mathrm{MnO}_{2}$, or $\mathrm{MgO}$ lowered the viscosity of the slag. Hurst et al. [27,72] measured the viscosity and $\mathrm{T}_{\mathrm{cv}}$ of synthetic melts containing 5, 10, and $15 \mathrm{wt} \%$ $\mathrm{FeO}$ of the $\mathrm{SiO}_{2}-\mathrm{Al}_{2} \mathrm{O}_{3}-\mathrm{CaO}-\mathrm{FeO}$ (SACF) quaternary system. Inaba and Kimura [73] created synthetic slag from carbon-bearing $\mathrm{FeO}$ pellets to study slag viscosities with temperature and chemical compositions in iron and steel making. Groen et al. [74] investigated slag viscosity with up to $30 \%$ of $\mathrm{TiO}_{2}$ addition on $\mathrm{FeO}-\mathrm{CaO}-\mathrm{Al}_{2} \mathrm{O}_{3}-\mathrm{SiO}_{2}$.

Slag viscosity with temperature and composition dependency can be measured or predicted using empirical models. Viscosity models can be used to evaluate coal suitability for entrained-flow gasification. Using thermodynamic models and viscosity models together, it is possible to simulate slag flow behavior in the gasifier as a function of gas composition and operating temperature. In addition, it can be used to analyze coal flux and blends [28]. For entrained-flow gasifiers, it is important that the models describe the viscosity of fully liquid slag in multi-component slag systems and also predict the viscosity of partly crystallized liquid slag. For predicting the viscosity of homogeneous liquid slag, the models of Urbain, Fereday, and the silica percentage model are used, as well as modified versions of those models (such as Kalmanovitch-Urbain, Watt and Fereday, and $\left.\mathrm{S}^{2}\right)[68,75,76]$. The main challenge of all these models is their validity over a limited composition and temperature range, and their accuracy for different slag systems (e.g., Kalmanovitch model best predicts western coal slag above $1350{ }^{\circ} \mathrm{C}$ [77]). To predict the viscosity of the crystalline phase slags, Annen's or Einstein's models were used [68,76]. Most viscosity models are based on particular viscosity datasets and, therefore, can predict slag viscosity only for the specific compositions and temperatures. Developing accurate, reliable, and general viscosity models that can be used for the multiple compositions in the slag and wide temperature ranges are necessary. Part II of this paper discusses viscosity modeling in more detail. 


\subsection{Slag Behavior with Oxygen/Carbon Ratio and Unreacted Carbon}

Oxygen/carbon ratio is an important operating condition along with steam/carbon ratio, carrier gas/solid ratio, and gasification pressure [78]. Dai et al. [78] studied all four conditions using the pilot-scale coal entrained-flow gasification system. The oxygen/carbon ratio affected the gasification temperature, carbon conversion, and syngas composition (e.g., $\mathrm{CO}+\mathrm{H}_{2}$ content) [30,78,79]. The steam/carbon ratio and carrier gas/solid ratio should be adjusted simultaneously with oxygen/carbon ratio changes [78]. As the oxygen/carbon ratio increases the gasification temperature and carbon conversion increase, resulting in less unburned carbon in ash and more ash depositing to the wall [79]. Wu et al. [80] reported that carbon contents were $60 \%$ in coarse slag and $30 \%-35 \%$ in fine slag because the oxygen/carbon ratio decreased in summer when ASU has a lower oxygen production.

Unreacted/unburned carbon in ash increased ash melting temperature and acted as a dispersive material in the deposit ash and prevented complete sintering in the slag even at high temperature [79]. Li et al. [16] studied ash deposition behavior at various conversions of a bituminous coal under gasification conditions using a laminar entrained-flow reactor and a deposition probe. The results showed that the stickiness of pulverized bituminous coal ash is a function of carbon conversion at temperatures above the ash fluid temperature. At critical carbon conversion, large amounts of included (inherent) minerals are exposed on the particle surface and melt, thus increasing the particle stickiness dramatically. The particle capture efficiency measures the ash deposition propensity and is a function of coal conversion. For Illinois \#6 coal, the critical carbon conversions are about $88 \%$ at $1400{ }^{\circ} \mathrm{C}$ and $93 \%$ at $1500{ }^{\circ} \mathrm{C}$ (Figure 7). These results were similar with the coal char-slag transition under oxidizing conditions [81]. This can be explained by studying slag surface characteristics and performing melting tests on mixtures of fine carbon and slag [82]. In the slag, fine inorganic matter tends to agglomerate into a carbon-free ball, existing in spherical shape, whereas residual carbons tend to stay as loose floccules. Therefore, carbon conversion is an important factor to maintaining slag flow in the gasifier and to limiting the amount of fly ash that may cause fouling in the syngas cooler.

Figure 7. Particle collection efficiency as a function of coal conversion [16].

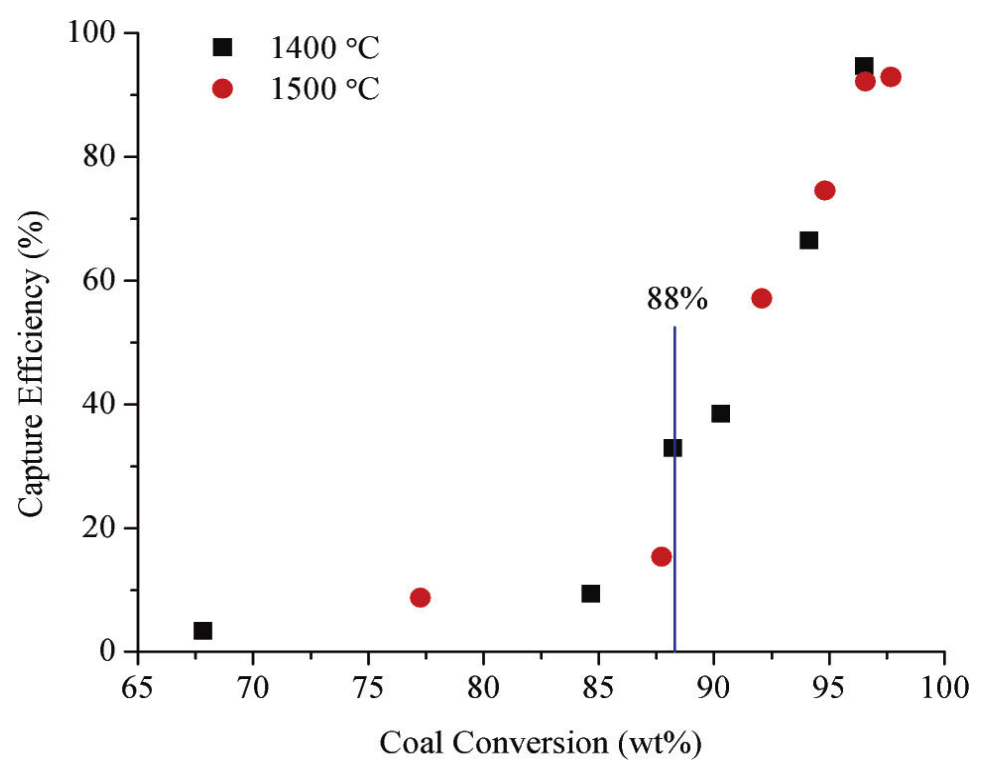




\subsection{Viscosity with Flux Agents and in Reducing Gas Environments}

In slagging operations, it may be desirable to add fluxing agents to improve the flow characteristics of the slag by adjusting its chemical behavior. Agents containing $\mathrm{Ca}, \mathrm{Mg}, \mathrm{Ba}$, and $\mathrm{B}$ can lower viscosity at a given temperature in a particular point of the viscosity-temperature curve [83], so that coals with high ash-flow temperature can be used and the gasifier can be operated at lower temperature, resulting in lower refractory wear and higher efficiency. Preferable flux agents include limestone $\left(\mathrm{CaCO}_{3}\right)$ and dolomite $\left(\mathrm{CaMg}\left[\mathrm{CO}_{3}\right]_{2}\right)$ due to their availability, low cost, and elevated $\mathrm{Ca}$ and $\mathrm{Mg}$ contents [22]. ( $\mathrm{Mg}, \mathrm{Fe})_{2} \mathrm{SiO}_{4}$ (such as olivine) is also a possible agent and can be used at lower levels than Ca-based components [83]. Vuthaluru and French [84,85] studied the ash deposition behavior of an Indonesian coal and found that ash with a lower glass content and higher crystalline content has a lower tendency to adhere on the deposition probe. The use of bauxite as a flux agent reduces the glass content and increases the crystalline content in coal ash. Additional Al may not be financially sound for many coal slags already contain significant amounts of Al [83].

At ash flow temperatures higher than $1500{ }^{\circ} \mathrm{C}$, a flux addition, such as limestone, is required [26]. The measurements of slag viscosity versus temperature at selected levels of flux addition for Australian coal A and B are shown in Figure 8 [26]. The figure shows that increasing amounts of fluxant reduces the viscosity, and the amount of fluxant required depends on the type of coal. To reduce flux cost, coal with $<3 \%$ flux requirement by weight may be blended with other coal possessing low ash fusion characteristics, thus reducing or eliminating the need for flux [26]. The viscosity contour as a function of composition or viscosity models could be used to calculate the amount of flux required to obtain a proper viscosity for smooth slag flow in an entrained-flow gasifier [27]. In addition, adding a flux agent increases ash content; therefore, the amount of added agent should be considered. The ash content for slurry feeding gasifiers is generally about $20 \%$ (consider evaporating water by heat) and about $40 \%$ for dry feeding gasifiers based on cost estimates and economic analysis [20]. Furthermore, a large amount of agent may cause downstream problems like fouling in the syngas cooler by mineral precipitation, and increasing $\mathrm{CO}_{2}$ generated in syngas, since $\mathrm{CO}$ must be burned to generate more heat for melting the agents [83].

Figure 8. Viscosity versus temperature curves for selected coal ash at various flux addition ratios [26]. (a) Coal ash A; (b) Coal ash B.

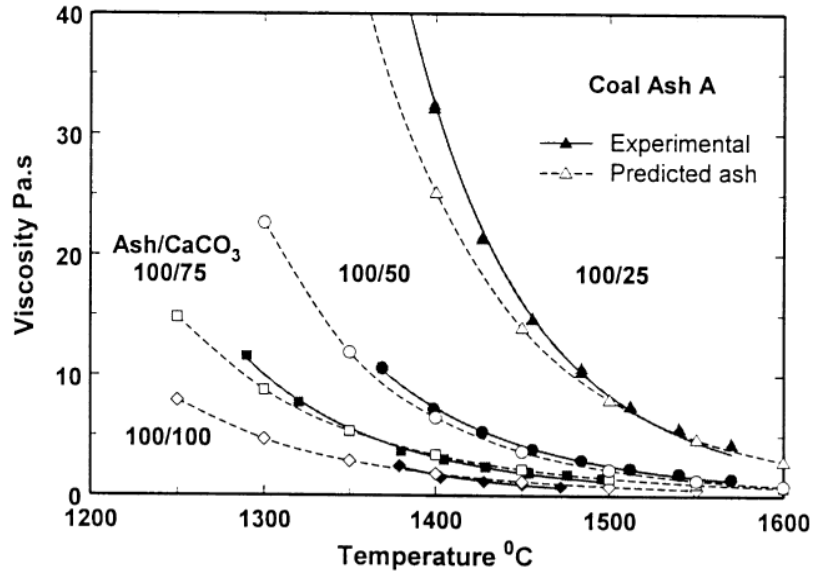

(a)

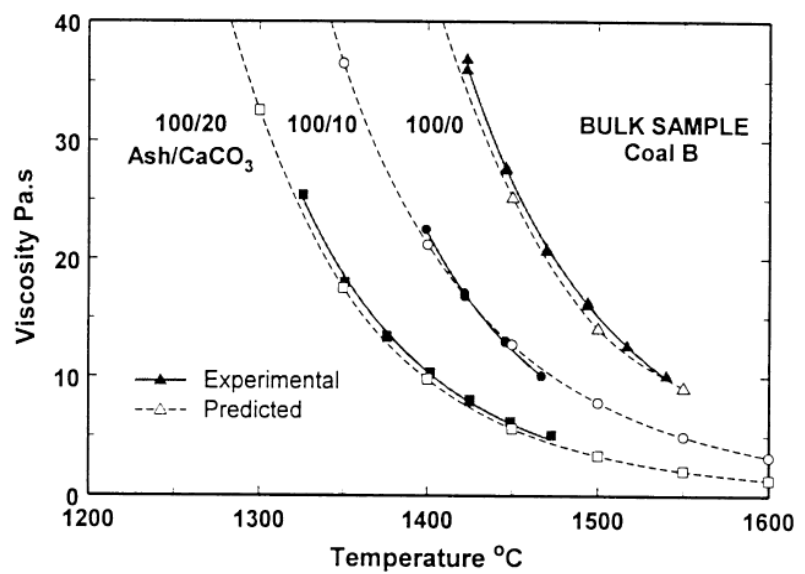

(b) 
Gasification takes place in a reducing environment, with $\mathrm{H}_{2}$ and $\mathrm{CO}$ as the dominant gases. The viscosity of Powder River Basin slag in three atmospheric conditions was studied [86]. The results show that slag viscosity is not substantially different in air or air $+10 \%$ water vapor, but it is substantially reduced in $\mathrm{H}_{2} / \mathrm{CO} / \mathrm{CO}_{2}$. Huffman et al. [57] investigated the behavior of coal ash in reducing $\left(60 \% \mathrm{CO} / 40 \% \mathrm{CO}_{2}\right)$ and oxidizing (air) atmospheres using SEM and XRD. The ash partially melts at temperatures $200-400{ }^{\circ} \mathrm{C}$ lower than the IDT from the AFT. Under reducing atmospheric conditions, ash melted faster than under oxidizing atmospheres. The percentage of melting ash increased rapidly at the range of $900-1100{ }^{\circ} \mathrm{C}$. Ash melting is primarily controlled using $\mathrm{Fe}$ as the flux agent. Under oxidizing conditions, $\mathrm{K}$ is the main flux agent at low temperature.

\section{Concluding Remarks}

For IGCC technology to become more competitive and fully commercial, low availability and high capital costs must be overcome [7,8]. In the entrained flow gasifiers used in IGCC plants, the low availability in the gasification system is largely due to the slag buildup in the gasifier and the fouling in the syngas cooler downstream of the gasification system in gasification section. All these issues are related to slag flow behaviors that are influenced by fuel properties and operating conditions. The viscosity of the slag is used to characterize slag flow behaviors and strongly depends on the temperature and chemical composition of the slag. Coal has varying ash content and composition, and therefore requires different operating conditions to maintain slag flow and limit downstream problems.

When selecting the gasifier operating temperature, considerations must be given to the ash slagging temperature or ash flow temperature of the coal, slag viscosity as $\mathrm{T}_{25}$ (the temperature at which the slag viscosity is $25 \mathrm{~Pa} \cdot \mathrm{s}), \mathrm{T}_{\mathrm{cv}}$, carbon conversion, and refractory life. High unconverted carbon in the ash affects ash deposition on the wall of the gasifier [16]. Fly ash with high amounts of unconverted carbon causes difficulties in downstream processing [9]. Low temperature and high slag viscosity may solidify the slag and cause slag blockage [9]. These complications may be rectified by sending more oxygen to the gasifier to burn more coal and generate more heat. However, this reduces the overall efficiency of an IGCC system by increasing the parasitic power load of the air separation unit, reducing syngas yield, and shortening the refractory life in cases where a refractory-lined gasifier is used. For most coals, the ash melting point and slag viscosity are more constraining than carbon conversion considerations [9].

Coal ash content, ash fusion temperature, slag viscosity, and $\mathrm{T}_{\mathrm{cv}}$ impact gasifier operating conditions and gasifier performance and are the key criteria in assessing a coal's suitability for an entrained-flow gasifier. Due to economic considerations, the ash content for slurry feeding gasifiers is generally about $20 \%$ (consider evaporating water by heat) and for dry feeding gasifiers is about $40 \%$. Slag viscosity of 15-25 $\mathrm{Pa} \cdot \mathrm{s}$ is required to ensure continuous slag flow. Lower $\mathrm{T}_{\mathrm{cv}}$ and ash flow temperature under a reducing environment is preferred to allow lower gasification temperature and thus higher cold gas efficiency. For coals with flow temperatures higher than $1500{ }^{\circ} \mathrm{C}$, flux must be added.

One option to reduce slag viscosity is to raise the gasifier operating temperature. The other option is to add a flux or blend coals with low fusibility, since viscosity is affected by chemical compositions of ash. However, to raise the operating temperature significantly increases the oxygen demand and the 
overall cost. Further study is needed to balance these two factors and achieve higher process efficiency and low costs. Correlating the properties and operating conditions to the behaviors of slagging could assist the selection of coals and enhance the performance of the entrained-flow gasifiers. Optimal operating conditions could improve both gasification efficiency and availability.

Bituminous coals, and petroleum coke blends with coals have been widely used in IGCC. Driven by the need to reduce $\mathrm{CO}_{2}$ emissions, renewable biomass may be used as an energy source [87]. In addition, low-rank coals (sub-bituminous and lignite) are a major but unused energy resource in the United States. Given the low price of low-rank coals compared to bituminous coal, using low rank coals could remain competitive to low-price natural gas for power generation in the future [88]. These fuels have different ash compositions and impact the slag behavior in the gasifiers. Wood has a poor slag behavior for entrained-flow gasifiers designed for fuels with higher than $6 \%$ solid content due to low ash content (typical 1\% w/w) and high alkali and alkaline earth metals [89]. Possible solutions are slag recycle and flux additions of silica and/or clay based materials, which is different than flux used in coal because $\mathrm{Ca}$ is the dominant inorganic component in wood ash. In addition, the alkali metals may be vaporized at high temperature in the gasifier and leave the gasifier with the syngas and adhere to the syngas cooler [30,90]. Sodium compounds $(\mathrm{NaCl}$ or $\mathrm{NaOH})$ and other alkali matter diffuse into the refractory and shorten the refractory life [30]; accurate viscosity models need to be developed for these fuels.

\section{References}

1. Falcke, T.J.; Hoadley, A.F.A.; Brennan, D.J.; Sinclair, S.E. The sustainability of clean coal technology: IGCC with/without CCS. Process. Saf. Environ. Prot. 2011; 89, 41-52.

2. U.S. Department of Energy. Office of Fossil Energy. Pioneering Gasification Plants. Available online: http://www.fossil.energy.gov/programs/powersystems/gasification/gasificationpioneer.html (accessed on 20 September 2012).

3. Integrated Gasification Combined Cycle (IGCC) Design Considerations for High. AvailabilityVolume 1: Lessons from Existing Opeations; Electric Power Research Institute: Palo Alto, CA, USA, 2007.

4. Higman, C.; Della Villa, S.; Steele, B. The Reliability of IGCC Power Generation Units. In Proceedings of the World Exhibition Congress on Chemical Engineering, Environmental Protection and Biotechnology (ACHEMA), Frankfurt, Germany, 18-22 May 2006.

5. The Wabash River Coal Gasification Repowering Project; Topical Report Number 7; U.S. Department of Energy: Washington, DC, USA, 1995.

6. The CURC-EPRI Coal Technology Roadmap; The Coal Utilization Research Council and the Electrc Power Research Instutue: Washington, DC, USA, 2012.

7. Maurstad O. An Overview of Coal Based Integrated Gasification Combined Cycle (IGCC) Technology; Massachusetts Institute of Technology: Cmabridge, MA, USA, 2005. Available online: http://sequestration.mit.edu/pdf/LFEE_2005-002_WP.pdf (accessed on 10 August 2012).

8. Trapp, B.; Moock, N.; Denton, D. Coal Gasification: Ready for Prime Time Power. Available online: http://www.clean-energy.us/projects/eastman_power_magazine.htm (accessed on 15 September 2012). 
9. Coal Fleet RD\&D Augmentation Plan for Integrated Gasification Combined Cycle (IGCC) Power Plants; Electric Power Research Institure: Palo Alto, CA, USA, 2006.

10. McDaniel, J. Tampa Electric Polk Power Station Integrated Gasification Combined Cycle Project: Final Technical Report; Tampa Electric Company Polk Power Station. Available online: http://www.tampaelectric.com/data/files/PolkDOEFinalTechnicalReport.pdf (accessed on 24 July 2012).

11. Mondal, P.; Dang, G.S.; Garg, M.O. Syngas production through gasification and cleanup for downstream applications-Recent developments. Fuel Process. Technol. 2011, 92, 1395-1410.

12. Wang, P.; Massoudi, M. Effect of Ash Properties and Operation Conditions on Flow Behavior of Coal Slag in Entrained Flow Gasifier: A Brief Review; DOE Report 1036451; U.S. Department of Energy, National Energy Technology Laboratory: Pittsburgh, PA, USA, 2011. Available online: http://www.osti.gov/servlets/purl/1036451 (accessed on12 September 2012).

13. Brooker, D. Chemistry of deposit formation in a coal-gasification syngas cooler. Fuel 1993, 72, 665-670.

14. Brooker, D.D.; Oh, M.S. Iron sulfide deposition during coal-gasification. Fuel Process. Technol. 1995, 44,181-190.

15. Erickson, T.A.; Allan, S.E.; McCollor, D.P.; Hurley, J.P.; Srinivasachar, S.; Kang, S.G.; Baker, J.E.; Morgan, M.E.; Johnson, S.A.; Borio, R. Modeling of fouling and slagging in coal-fired utility boilers. Fuel Process. Technol. 1995; 44, 155-171.

16. Li, S.H.; Wu, Y.X.; Whitty K.J. Ash deposition behavior during char-slag transition under simulated gasification conditions. Energy Fuels 2010; 24, 1868-1876.

17. Yong, S.Z.; Ghoniem, A. Modeling the slag layer in solid fuel gasification and combustiontwo-way coupling with CFD. Fuel 2012; 97, 457-466.

18. Wang, H.F.; Harb, J.N. Modeling of ash deposition in large-scale combustion facilities burning pulverized coal. Prog. Energy Combust. Sci. 1997; 23, 267-282.

19. Ni, J.J.; Yu, G.S.; Guo, Q.H.; Zhou, Z.J.; Wang, F.C. Submodel for predicting slag deposition formation in slagging gasification systems. Energy Fuels 2011; 25, 1004-1009.

20. Higman, C.; van der Burgt, M. Gasification, 2nd ed.; Elsevier: New York, NY, USA, 2008.

21. Guo, Z.Q.; Han, B.Q.; Dong, H. Effect of coal slag on the wear rate and microstructure of the $\mathrm{ZrO}_{2}$-bearing chromia refractories. Ceram. Int. 1997, 23, 489-496.

22. Duchesne, M.A.; Macchi, A.; Lu, D.Y.; Hughes, R.W.; McCalden, D.; Anthony, E.J. Artificial neural network model to predict slag viscosity over a broad range of temperatures and slag compositions. Fuel Process. Technol. 2010; 91, 831-836.

23. Ni, J.J.; Zhou, Z.J.; Yu, G.S.; Liang, Q.F.; Wang, F.C. Molten slag flow and phase transformation behaviors in a slagging entrained-flow coal gasifier. Ind. Eng. Chem. Res. 2010, 49, 12302-12310.

24. Roberts, D.G.; Harris, D.J.; Tremel, A.; Ilyushechkin, A.Y. Linking laboratory data with pilot scale entrained flow coal gasification performance-Part 2: Pilot scale testing. Fuel Process. Technol. 2012; 94, 26-33.

25. Kinaev, N. A Review of Mineral. Matter Inssues in Coal Gasification; CSIRO Energy Technology Transfer Center: Pullenvale, Australia, 2006.

26. Patterson, J.H.; Hurst, H.J. Ash and slag qualities of Australian bituminous coals for use in slagging gasifiers. Fuel 2000, 79, 1671-1678. 
27. Hurst, H.J.; Novak, F.; Patterson, J.H. Viscosity measurements and empirical predictions for fluxed Australian bituminous coal ashes. Fuel 1999; 78, 1831-1840.

28. Kondratiev, A.; Jak, E.; Hayes, P.C. Slag Viscosity Prediction and Characterization $\mathrm{Al}_{2} \mathrm{O}_{3}-\mathrm{CaO}-$ 'Feo'-SiO2 and $\mathrm{Al}_{2} \mathrm{O}_{3}-\mathrm{CaO}$ - 'Feo'- $\mathrm{MgO}-\mathrm{SiO}_{2}$ Systems; CCSD Research Report 58; The University of Queensland: Queensland, Australia, 2006.

29. de Graaf, J.D. Shell Coal Gasification Technology. Shell Global Solution. Available online:

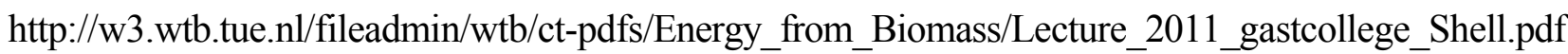
(accessed on 6 June 2012).

30. Cortés, C.G.; Tzimas, E.; Peteves, S.D. Technologies for Coal Based Hydrogen and Electricity Co-production Power Plants with $\mathrm{CO}_{2}$ Capture; EUR 23661/EN-2009, 2009. Available online: http://www.energy.eu/publications/a05.pdf (accessed on 18 July 2012).

31. Breault, R.W. Gasification processes old and new: a basic review of the major technologies. Energies 2010; 3, 216-40.

32. Gasification: Gasification in Detail Type of Gasifiers; National Energy Technology Laboratory: Morgantown, WV, USA, 2012. Available online: http://www.netl.doe.gov/technologies/ coalpower/gasification/gasifipedia/4-gasifiers/4-1-2_entrainedflow.html (accessed on 20 May 2012).

33. Gasification Technology Status; Electric Power Research Institute: Palo Alto, CA, USA, 2006.

34. Siemans. Simens fuel gasification technology. Available online: http://www.energy.siemens.com /hq/pool/hq/power-generation/fuel-gasifier/downloads/brochure_fuel_gasifier_en.pdf2008 (accessed on 15 September 2012).

35. Sundaram, S.K.; Johnson, K.I.; Matyas, J.; Williford, R.E.; Pilli, S.P.; Korolev, V.N. An integrated approach to coal gasifier testing, modeling, and process optimization. Energy Fuels 2009; 23, 4748-4754.

36. Kaneko, T.K.; Zhu, J.; Thomas, H.; Bennett, J.P.; Sridhar, S. Influence of oxygen partial pressure on synthetic coal slag infiltration into porous $\mathrm{Al}_{2} \mathrm{O}_{3}$ refractory. J. Am. Ceram. Soc. 2012, 95, 1764-1773.

37. Kaneko, T.K.; Bennett, J.P.; Sridhar, S. Effect of temperature gradient on industrial gasifier coal slag infiltration into alumina refractory. J. Am. Ceram. Soc. 2011, 94, 4507-4515.

38. Yun, Y.S.; Yoo, Y.D.; Chung, S.W. Selection of IGCC candidate coals by pilot-scale gasifier operation. Fuel Process. Technol. 2007, 88,107-116.

39. Wang, P.; Massoudi, M. Impact of Coal and Operating Conditions on the Behavior of Coal Slag in Gasifiers. In Porceedings of 243rd ACS National Meeting \& Exposition, San Diego, CA, USA, 25-29 March 2012.

40. Ward, C.R. Analysis and significance of mineral matter in coal seams. Int. J. Coal Geol. 2002, 50, $135-168$.

41. Miller, B.G. Coal Energy System; Elsevier: Burlington, MA, USA, 2005.

42. Erickson, T.A.; Brekke, D.W.; Tibbetts, J.E.; Folkedahl, B.C. Techniques for Determining Inorganic Transformations During Entrained-Flow Coal Gasification. In The Impact of Ash Deposition on Coal Fired Plants; Williamson, J., Wigley, F., Eds.; Taylor \& Francis: Washington, DC, USA, 2004.

43. Van Dyk, J.C.; Benson, S.A.; Laumb, M.L.; Waanders, B. Coal and coal ash characteristics to understand mineral transformations and slag formation. Fuel 2009; 88, 1057-1063. 
44. Matjie, R.H.; French, D.; Ward, C.R.; Pistorius, P.C.; Li, Z.S. Behaviour of coal mineral matter in sintering and slagging of ash during the gasification process. Fuel Process. Technol. 2011; 92, 1426-1433.

45. Matsuoka, K.; Suzuki, Y.; Eylands, K.E.; Benson, S.A.; Tomita, A. CCSEM study of ash forming reactions during lignite gasification. Fuel 2006, 85 ,2371-2376.

46. Reid, W.T. Its Effect on Combution System; Wiley: New York, NY, USA, 1981.

47. Aineto, M.; Acosta, A.; Rincon, J.M.; Romero, M. Thermal expansion of slag and fly ash from coal gasification in IGCC power plant. Fuel 2006, 85, 2352-2358.

48. Font, O., Querol, X., Huggins, F.E.; Chimenos, J.M.; Fernandez, A.I.; Burgos, S.; Pena, F.G. Speciation of major and selected trace elements in IGCC fly ash. Fuel 2005, 84, 1364-1371.

49. Van Dyk, J.C.; Waanders, F.B.; Benson, S.A.; Laumb, M.L.; Hack, K. Viscosity predictions of the slag composition of gasified coal, utilizing FactSage equilibrium modelling. Fuel 2009, 88, 67-74.

50. Song, W.J.; Tang, L.H.; Zhu, X.D.; Wu, Y.Q.; Rong, Y.Q.; Zhu, Z.B.; Koyama, S. Fusibility and flow properties of coal ash and slag. Fuel 2009; 88, 297-304.

51. Wang, H.G.; Qiu, P.H.; Zhu, Y.; Wu, S.J.; Zhao, W.H.; Wu, S.H. Effect of residence time on coal ash behavior at high temperatures in reducing atmosphere. Energy Fuels 2011, 25, 5594-604.

52. Su, S.; Pohl, J.H.; Holcombe, D. Fouling propensities of blended coals in pulverized coal-fired power station boilers. Fuel 2003, 82, 1653-1667.

53. Su, S.; Pohl, J.H.; Holcombe, D. Hart, J.A. Slagging propensities of blended coals. Fuel 2001, 80, 1351-1360.

54. Xu, L.H.; Namkung, H.; Kwon, H.B.; Kim, H.T. Determination of fouling characteristics of various coals under gasification condition. J. Ind. Eng. Chem. 2009, 15, 98-102.

55. Speight, J.G. Handbook of Coal analysis; Wiley: New York, NY, USA, 2005.

56. Bryant, G.W.; Browning, G.J.; Emanuel, H. Gupta, S.K.; Gupta, R.P.; Lucas, J.A.; Wall, T.F. The fusibility of blended coal ash. Energy Fuels 2000, 14, 316-325.

57. Huffman, G.P.; Huggins, F.E.; Dunmyre, G.R. Investigation of the high-temperature behavior of coal ash in reducing and oxidizing atmospheres. Fuel 1981, 60, 585-597.

58. Hurst, H.J.; Novak, F.; Patterson, J.H. Phase diagram approach to the fluxing effect of additions of $\mathrm{CaCO}_{3}$ on Australian coal ashes. Energy Fuels 1996, 10, 1215-1219.

59. Winegartner, E.C.; Rhodes, B.T. Empirical-study of relation of chemical properties to ash fusion temperatures. J. Eng. Power Trans. ASME 1975, 97, 395-406.

60. Song, W.J.; Tang, L.H.; Zhu, X.D.; Wu, Y.Q.; Zhu, Z.B.; Koyama, S. Effect of coal ash composition on ash fusion temperatures. Energy Fuels 2010, 24, 182-189.

61. van Dyk, J.C. Understanding the influence of acidic components ( $\mathrm{Si}, \mathrm{Al}$, and Ti) on ash flow temperature of South African coal sources. Miner. Eng. 2006, 19, 280-286.

62. Massoudi, M., Wang, P. A Brief Review of Viscosity Models for Slag in Coal Gasification; DOE Report 103673; U.S. Department of Energy, National Energy Technology Laboratory: Pittsburgh, PA, USA, 2012. Available online: www.osti.gov/servlets/purl/1036735 (accessed on 20 September 2012).

63. Schobert, H.H.; Streeter, R.C.; Diehl, E.K. Flow properties of low-rank coal ash slagsimplications for slagging gasification. Fuel 1985, 64, 1611-1617. 
64. Yuan, H.P.; Liang, Q.F.; Gong, X. Crystallization of coal ash slags at high temperatures and effects on the viscosity. Energy Fuels 2012, 26, 3717-3722.

65. Ilyushechkin, A. Kinaev, N. Part 2-Studies of the Connection Between Tcv and Phase Composition of Molten Slag; Technial Note 25; CSIRO Energy Technology: Pulenvale, Australia, 2007. Available online: http://www.ccsd.biz/publications/files/TN/TN\%2025_Effects\%20of \%20K_web.pdf (accessed on 12 May 2012).

66. Song, W.J.; Dong, Y.H.; Wu, Y.Q.; Zhu, Z.B. Prediction of temperature of critical viscosity for coal ash slag. AICHe J. 2011, 57, 2921-2925.

67. Jak, E.; Saulov, D.; Kondratiev, A.; Hayes, P.C. Prediction of phase equilibria and viscosity in complex coal ash slag systems. Abstr. Papers Am. Chem. Soc. 2004, 227, 1079.

68. Oh, M.S.; Brooker, D.D.; Depaz, E.F.; Brady, J.J.; Decker, T.R. Effect of crystalline phase-formation on coal slag viscosity. Fuel Process. Technol. 1995, 44, 191-199.

69. Lin, X.C.; Ideta, K.; Miyawaki, J.; Takebe, H. Yoon, S.H.; Mochida, I. Correlation between fluidity properties and local structures of three typical asian coal ashes. Energy Fuels 2012, 26, 136-144.

70. Kinaev, N.; Ilyushechkin, A. Slag Viscosity-Effects of Potassium and Phase Composition; Technial Note 25; CSIRO Energy Technology: Pulenvale, Australia, 2007. Available online: http://www.ccsd.biz/publications/files/TN/TN\%2025_Effects\%20of\%20K_web.pdf (accessed on 12 August 2012).

71. Kato, M.; Minowa, S. Viscosity measurements of molten slag. Trans. Iron Steel Inst. Jpn. 1969, 9, $31-38$.

72. Hurst, H.J.; Patterson, J.H.; Quintanar, A. Viscosity measurements and empirical predictions for some model gasifier slags-II. Fuel 2000, 79, 1797-1799.

73. Inaba, S.; Kimura, Y. Viscosity measurement of slag formed in the carbon-bearing iron oxide during the rapid heating. Iron Steel Inst. Jpn. Int. 2004, 44, 2067-2072.

74. Groen, J.C.; Brooker, D.D.; Welch, P.J.; Oh, M.S. Gasification slag rheology and crystallization in titanium-rich, iron-calcium-aluminosilicate glasses. Fuel Process. Technol. 1998, 56, 103-127.

75. Browning, G.J.; Bryant, G.W.; Hurst, H.J.; Lucas, J.A.; Wall, T.F. An empirical method for the prediction of coal ash slag viscosity. Energy Fuels 2003, 17, 731-737.

76. Song, W.J.; Sun, Y.M.; Wu, Y.Q.; Zhu, Z.B.; Koyama, S. Measurement and simulation of flow properties of coal ash slag in coal gasification. AICHe J. 2011, 57, 801-818.

77. Zhu, J.X.; Kaneko, T.K.; Mu, H.Y.; Bennett, J.P.; Sridhar, S. Effects of measurement materials and oxygen partial pressure on the viscosity of synthetic eastern and western united states coal slags. Energy Fuels 2012, 26, 4465-4474.

78. Dai, Z.; Gong, X., Guo, X.L.; Liu, H.; Wang, F.C.; Yu, Z. Pilot-trial and modeling of a new type of pressurized entrained-flow pulverized coal gasification technology. Fuel 2008, 87, 2304-2313.

79. Koyama, S.; Morimoto, T.; Ueda, A.; Matsuoka, H. A microscopic study of ash deposits in a two-stage entrained-bed coal gasifier. Fuel 1996, 75, 459-465.

80. Wu, T.; Gong, M.; Lester, E.; Wang, F.C.; Zhou, Z.J.; Yu, Z.H. Characterisation of residual carbon from entrained-bed coal water slurry gasifiers. Fuel 2007, 86, 972-82.

81. Li, S.H.; Whitty, K.J. Investigation of coal char-slag transition during oxidation: effect of temperature and residual carbon. Energy Fuels 2009, 23, 1998-2005. 
82. Zhao, X.L.; Zeng, C.; Mao, Y.Y.; Li, W.H.; Peng, Y.; Wang, T.; Eiteneer, B.; Zamansky, V.; Fletcher, T. The surface characteristics and reactivity of residual carbon in coal gasification slag. Energy Fuels 2010, 24, 91-94.

83. Brannon, M.J.; Ollis, G.W.; Shoaf, G.L. Expanding the range of suitable gasification fuels. Fuel Process. Technol. 2012, 99, 1-5.

84. Vuthaluru, H.B.; French, D. Ash chemistry and mineralogy of an Indonesian coal during combustion-Part 1 drop-tube observations. Fuel Process. Technol. 2008, 89, 595-607.

85. Vuthaluru, H.B.; French, D. Ash chemistry and mineralogy of an Indonesian coal during combustion: Part II-Pilot scale observations. Fuel Process. Technol. 2008, 89, 608-621.

86. Hurley, J.; Wang, T.M.; Nowir, J.W. The Effects of Atmosphere and Additives on Coal Slag Viscosity; Available online: http://www.anl.gov/PCS/acsfuel/preprint\%20archive/Files/41_2_ NEW\%20ORLEANS_03-96_0691.pdf (accessed on 20 June 2012).

87. Wang, P.; Shuster, E.; Matuszewski, M.; Tarka, T.; Van Essendelft, D.; Berry, D. Selection of biomass type for co-gasification studies. In Proceedings of the 35th International Technical Conference on Clean Coal \& Fuel Systems, Clearwater, FL, USA, 6-10 June 2010.

88. Tubio, M.; Riddle, K.; Quinones, H.; Meskers, D. Opportunity Coal Slag Control at Lakeland Mclntosh Unit\#3; Technical Report; GE Energy: Fairfield, CT, USA, 2011.

89. Coda, B.; Cieplik, M.K.; de Wild, P.J.; Kiel, J.H.A. Slagging behavior of wood ash under entrained-flow gasification conditions. Energy Fuels 2007, 21, 3644-3652.

90. Matsumoto, K., Takeno, K., Ichinose, T., Ogi, T., Nakanishi, M. Behavior of alkali metals as the carbonate compounds in the biomass char obtained as a byproduct of gasification with steam and oxygen at 900-1000 degrees C. Energy Fuels 2010, 24, 1980-1986.

(C) 2013 by the authors; licensee MDPI, Basel, Switzerland. This article is an open access article distributed under the terms and conditions of the Creative Commons Attribution license (http://creativecommons.org/licenses/by/3.0/). 